\title{
Chapter 9 \\ Practices in Focus: The Dilemmas \\ That Evoke them and the Effects \\ They Have
}

This study investigated a problem that can be expressed in two broad questions. Under what circumstances do decision makers work, and how can those circumstances be explained? How do officials deal with these circumstances, that is, the structural tensions, and how can their practices be explained? My approach to exploring these questions was a case study that was inspired by institutional ethnography and adopted the combined analytical lens of social practice, structuration and (post-)constructivist theories. Throughout the book, I aimed to show how these theoretical perspectives complement each other on the basis of empirical findings. In closing, this chapter focuses on officials' practices and offers concluding theoretical remarks in this regard.

To understand the contextual factors of the case study, it was important to consider the external and internal circumstances of refugee status determination and how these circumstances interact. The international, supranational and national legal framework, asylum policies and jurisdiction of higher courts can be understood as an external environment that is, at least partly, already contradictory. Different orientations, such as human rights and restrictive policies, create conflicting logics in the field of asylum. However, the dilemmas are reinforced when we consider the internal circumstances of the FAO. The administration has its own organizational aims and is largely oriented toward the values of New Public Management - which was increasingly introduced in the Austrian context around the turn of the century - such as efficiency and outcome orientation. The mass processing of applications under limited resources creates the typical dilemmas of street-level bureaucracies. The findings illustrate that these circumstances produce the dilemmatic situation in which caseworkers find themselves when deciding asylum claims.

The original version of this chapter was revised.

An erratum to this chapter can be found at https://doi.org/10.1007/978-3-319-63306-0_12 
The concrete dilemmas that could be identified were regulation versus room for maneuver, definitiveness versus uncertainty, the human individual versus the faceless case, and responsibility versus dissociation. To some extent, these dilemmas can all be understood as typical dilemmas of a street-level bureaucracy. The fact that these dilemmas faced by officials in everyday work are comparable to those in other fields is highlighted by their similarity to the dilemmas described by Prottas (1979) and Lipsky (2010[1980]). Their works highlight three important dilemmas of the mediators between state institutions and their clients (Hjörne et al. 2010): (1) autonomy versus control, (2) responsiveness versus standardization and (3) demand versus supply. These "dilemma[s] of the individual in public service" (Lipsky 2010), which were also found in more recent works (Maynard-Moody and Musheno 2003; Dubois 2010; Hupe et al. 2015), can be understood as the tensions between conflicting norms and demands to which street-level workers' practices relate in everyday work (Hjörne et al. 2010 after Billig 1988). Thus, they represent the general dilemmas of bureaucratic action aimed at establishing the eligibility of individuals to access certain rights or benefits.

Two dilemmas in particular - that decision makers are confronted with heavy regulation but also possess undeniable room for maneuver and that caseworkers need to find a balance between processing the masses and recognizing the individual - are not specific to the asylum procedure, as the existing literature on streetlevel bureaucracies suggests. However, the asylum procedure creates additional dilemmas that seem more relevant here than in other settings. The two dilemmas, that officials need to make a definite decision in situations characterized by uncertainty and that they find themselves oscillating between responsibility and dissociation, can also be found in other street-level contexts but seem to be particularly critical in the asylum procedure. The first dilemma refers to the problem that the procedure is primarily about establishing past facts or proving a future risk, often with lacking evidence. The absence of evidence, which leads to the "construction" of facts in the asylum administration, is not a major problem in most other streetlevel bureaucracies. In addition, the issue of international protection, in which the right to life (article $2 \mathrm{ECHR}$ ) and the right not to be tortured (article $3 \mathrm{ECHR}$ ) are at stake, creates particularly far-reaching consequences of officials' decisions, which are made under conditions of uncertainty. Thus, the legal framework also makes the asylum procedure at least partly different from other street-level contexts. The other dilemma concerns the interpersonal interaction between the decision maker and the asylum claimant. In contrast to other street-level bureaucracies, cross-cultural challenges and working through interpreters are the norm in the asylum procedure (Barnes and Mackey 2013). In addition, many claimants have vulnerabilities inherent to their situation, making it necessary to consider psychological and traumatic dimensions. Taking these aspects into account, finding a balance between responsibility and dissociation - which is related to the dilemma between recognizing the individual and processing the masses - seems particularly tricky. 
The observation that these two dilemmas seem to be of special importance in the asylum procedure provokes a need to discuss two issues beyond traditional streetlevel bureaucracy theory. The first issue, the social construction of facts and (in) credibility as a particularity of the asylum procedure, was explored in detail in Chap. 6. The other issue that emerges is ethics (and ethical decision-making) in the bureaucratic context, which will be discussed in the concluding chapter.

The next question that I aimed to answer in this study was how caseworkers address these dilemmas and how their practices can be explained. I will briefly summarize which practices emerge from the four dilemmas following the sequence of chapters. In dealing with the first dilemma (regulation versus room for maneuver), caseworkers develop individual strategies and approaches, highlighting the importance of the subjective dimension of processing asylum claims. They have and make use of room for maneuver beyond discretionary power not only because legal and administrative norms allow it but also because it facilitates everyday work. This leeway gives decision makers a feeling of power and autonomy, a key issue in streetlevel bureaucracy theory. Confronted by the second dilemma (definitiveness versus uncertainty), officials engage in practices of constructing facts, artifacts (documents) and (in)credibility. Social construction appears to be a necessity in everyday work, and an explanation from the organizational perspective identifies these practices as transforming informality into formality. The third dilemma (the human individual versus the faceless case) is met by an extensive use of categorization made necessary by a focus on efficiency and "people processing." This practice again simplifies the otherwise intricate everyday work of deciding asylum claims; in addition, it represents a possibility of meeting the aims of NPM. The fourth dilemma (responsibility versus dissociation) causes officials to oscillate between practices of accepting and delegating responsibility. For some decision makers, their work (not only with traumatized persons) represents a heavy psychological burden. However, the organization does not seem to provide appropriate ways of dealing with responsibility. Additionally, the ethical aspects of decision-making and delegating responsibility are not addressed.

The question that emerges as a result concerns the effects of these practices. The fact that officials' practices differ - partly challenging or running counter to not only certain norms but also the organizational culture - produces a relatively unpredictable asylum procedure. This is also mirrored by the variance in recognition rates (as mentioned in the introduction). However, discretion and variance in the treatment of asylum claimants and their claims cannot be fully eliminated; they will always exist since the procedure consists not only of applying a general law to a specific case but also of interaction among humans. Together with the question of how the current situation can be approached or improved (giving rise to suggestions at different levels), these two issues will be discussed in the concluding chapter of the book. First, to summarize, the following two sections will explore the specific insights into the identified dilemmas and practices that can be provided by an analytical focus on social construction and an organizational sociology perspective. 


\subsection{From the Perspective of Structuration, Practice and Social Construction Theories}

Existing street-level bureaucracy theory helps to understand and explain the observed structural contradictions and officials' practices of handling them. Nevertheless, in each chapter - starting with the organizational context, continuing with the analysis of the asylum interview, and going into detail on the dilemmas - I aimed to account for the added value of practice and structuration theories, including a focus on organizational sociology and social construction, to analyze the circumstances of work at the FAO and officials' practices. The key concepts of practice theory - the materiality of practices as dependent on bodies and artifacts; the "informal," tacit logic of practices and the location of the social in practical understanding and know-how techniques; and the tension between routinization and the incalculability of social practices (Reckwitz 2003) - guided the analysis of officials' practices. In addition, the structurational approach (Ortmann et al. 2000; Giddens 2011) provided an exploration of the recursive relationship of agency and structure in organizational everyday work. ${ }^{1}$

The perspectives of structuration and praxeology also agree with a constructivist view, prompting an analysis of public officials' practices of construction - not only of facts but also of cases, categories, incredibility, or artifacts. In their seminal work on social construction, Berger and Luckmann [1975(1966)] observed the relationship between structure and agency as dialectical. Consequently, structuration can be understood as a theory regarding the way that social construction - as practice and modality - takes place and is effectuated by agents.

Little research has been conducted on social construction in public administration in general (Jun 2006) and in the asylum procedure in particular. In the context of asylum, the issue of social construction has been analyzed on the discourse and narrative level, mainly with regard to processes of categorization and labeling of asylum seekers (Zetter 2007; Innes 2010; Long 2013). Other studies focus on the social construction of asylum claimants (Lynn and Lea 2003; Lacroix 2004; Goodman and Speer 2007), and some work has been done on the construction of credibility in refugee status determination (Sweeney 2009; Noura 2006; Jubany 2017). However, there is still very little scientific understanding of the constructed character of the entire procedure, particularly with regard to the facts and artifacts within it.

Adopting a (post-)constructivist approach to how knowledge is established and enacted (Hacking 1999; Latour 2003), social construction is not only a cognitive but also a performative act. With the aim of exploring social practices beyond language use as such in the specific institutional context of an asylum authority, the social constructivist approach also allows the understanding of facts and artifacts (such as records) as social constructs (Latour and Wooglar 1986; Lowe 2004; Bijker and Pinch 2012). The constructed character of the asylum procedure is ubiquitous. The

${ }^{1}$ This section is partly based on an earlier publication (Dahlvik 2017b). 
procedure itself is not only a legal construct but also a social construct, as are its defining "elements" such as asylum claimants. In addition to constructions based on legal instruments, other forms of construction, deconstruction and reconstruction occur in administrative day-to-day work. Asylum claimants are constructed as essentialized group members (Goodman and Speer 2007), and their accounts, which they provide in the interviews, are subject to deconstruction and reconstruction in processing a claim.

The important role of social construction in the asylum procedure becomes visible through an analysis of practices along the three dimensions of structure (Giddens 2011): signification, domination and legitimation. This analysis provides insights into how the social structure constrains and enables the action of decisionmaking officials and how the latter reproduce and use rules and resources as "modeling clay." Social construction in the sense of this analysis is not only an interpretive scheme in the asylum procedure; it is also a facility or a resource that can be employed, and it can take the form of norms as well as shape norms in refugee status determination.

To define what constitutes a fact, what should be documented in a record, and what is credible or incredible, the involved actors make use of interpretive schemes. They ascribe meanings, but they also negotiate these meanings and put different weights on them. These practices are illustrated by the fact that different versions of reality, which have to be balanced against each other, are called into play in the asylum procedure. Through communication, those with the power of definition decide which of the meanings is valid in each specific "case." Social construction, cognitive and enacted, is thus also a facility or resource that can be employed by knowledgeable agents in different situations. Whereas one document is constructed - through negotiation - as a piece of evidence, another one is construed as "fake" or irrelevant. Domination and signification are thus closely interrelated in deciding what constitutes a fact, an artifact, (in-)credibility, and, in the long run, an asylum claim. These constructions are also informed by or oriented toward certain social, organizational, legal and other norms. As mentioned above, the search for facts is often norm-oriented, and a decision based on existing (legal) norms facilitates the legitimation of the official's decision. However, the construction of (in-) credibility is often based on other norms, such as the individual benchmarks and expectations of the decision maker. These findings show that in the asylum procedure, power is unequally distributed among all three dimensions of structure: signification, domination and legitimation.

The process of refugee status determination also illustrates the relations among communication, power and sanction - the three dimensions of interaction. The construction of facts, artifacts and (in-)credibility is based on oral (in particular, the asylum interview) and written (e.g., notifications, pieces of evidence) communication not only between the asylum claimant and government official but also among other actors. Within these communications, power plays a key role since the aim of each actor is to gain the power of definition. Asylum claimants, caseworkers, and experts struggle over who defines what constitutes a fact, what is worth being documented, and what is credible - and what is not. If an actor loses or never reaches the 
power of definition, s/he can be said to be sanctioned. Eventually, it is the asylum claimant who receives the final sanction - the decision upon her/his asylum claim based not only on the preceding communication and power interplay but also on the normative framework (the law as well as other social and organizational norms).

This theoretical approach highlights that power is unequally distributed, but it also suggests that interaction creates room for maneuver and interpretation, potentially also for those with less power of definition. Structuration theory implies that through their agency, officials - just as any other agent - have the opportunity to act differently, to create something new and to shape new "figurations" (Elias 1976). Caseworkers can, for example, develop new strategies for obtaining facts or define different documents as a legitimate source or regard other evidence as relevant to the record. The asylum procedure is thus characterized by transforming rules and resources and changing compositions and configurations of signification, domination and legitimation. Officials are not "caught" in or determined by the structural circumstances; instead, they contribute to the (re)production of those circumstances through their day-to-day actions. Structuration theory holds that knowledgeable individuals can use the available resources to change the norms or policies that the structure imposes on them. As Dubois (2010:137) notes, "[T]he agents employed by an institution and the people who have to deal with it always have a degree of leeway, and, in using it, develop practices that limit the institution's influence, or even transform it."

This approach also emphasizes that street-level bureaucracy is not only about discretion in the sense of "the right or ability to decide something" (Cambridge English Dictionary 2017) but also, essentially, about the room for maneuver in a broader sense and about agents' practices and strategies. Emphasizing their power, this "active" view of bureaucrats is also in line with the position that understands bureaucrats as policy makers since they are the ones who turn law into action (Brodkin 2011; Paquet 2015). In his seminal work, Lipsky (2010[1980]) argued that street-level bureaucrats, such as decision-making officials in the asylum procedure, "function as policy decision makers, as they wield their considerable discretion in the day-to-day implementation of public programs." Public officials not only implement policies but also contribute to them by understanding their roles and using resources in different ways, by making use of their room for maneuver in interpreting the given rules, and by attributing political meaning to their actions (Fassin 2015).

Squire's (2009:186) statement that we are all social actors capable of acting and organizing with significant consequences concerns civil society, asylum claimants and decision-making officials alike. As Mountz (2010:xxv) notes, decision-making officials potentially have the power to act subversively in everyday work, especially when policies are questioned and challenged by larger parts of society. According to Martinez (2009:116), an ethically acting caseworker should call attention to flaws in the system in order to allow reflection on and the implementation of change instead of abiding by the letter of the law because it was stipulated by the caseworker's superiors. "The embodied nation-state is articulated through, and in an important sense limited by, the imaginations of those who enact it" (Mountz 2010:xxv). 


\subsection{From the Organizational Perspective: Practices of Dealing with Formality and Informality}

Drawing on street-level bureaucracy theory in combination with practice and structuration theories is useful for understanding and explaining the findings of this case study. Furthermore, the perspective of organizational sociology provides additional insights regarding governmental action in the administration of asylum. The structural contradictions observed through decision makers' practices vis-à-vis dilemmas can be conceived as a tension between legal and administrative overregulation and the relative "triviality" of everyday work. This tension is expressed in the coexistence of the formality of legal and administrative norms and the informality of everyday work practices - an analytical distinction relating to the gap between law in the books and law in action (Pound 1910). The dilemmas thus represent the interplay between formality and informality, which relates to key issues of practice and structuration theories that emphasize the role of informality in social (and organizational) practices. Legal and administrative norms require

- adherence to rules, but everyday work - characterized by the interpretation and implementation of these norms - requires room for maneuver;

- a definite decision, but in everyday work, much is undecidable since the asylum procedure is characterized by uncertainty;

- orientation at the individual (human being), but everyday work is largely oriented toward the faceless case;

- responsibility, but everyday work is characterized by dissociation.

The identified dilemmas can thus be regarded from the perspective of formality and informality and caseworkers' related practices. While formality and informality coexist and are closely interwoven, they each regulate different areas. The findings illustrate how in processing asylum claims, officials practices are oriented toward both formal and informal frameworks in trying to find a balance. ${ }^{2}$

In organizational research, praxeological approaches represent a counterpole to classical economic theories such as rational choice or post-Weberian formal rationality in bureaucratic-hierarchical institutions. Since the 1980s, structurational organization studies have focused on recursive routines of action instead of rationalistic decision-making theories. Key topics are, for example, decisions under uncertainty and the related role of rules of thumbs and relations of trust. Actors are not normatively idealized as individuals following explicit institutional norms; by contrast, informal practices are assumed to govern the organizational everyday, which can also contravene official regulations (Reckwitz 2002; Martinez 2009). Caseworkers have the possibility to resist formal norms to some extent, for example, by ignoring those norms because they are impracticable in everyday work. In such situations, informality takes "the form of deviant action aimed at achieving the ends that the abstraction failed to achieve" (Stinchcombe 2001:7).

\footnotetext{
${ }^{2}$ This section is partly based on an earlier publication (Dahlvik 2017a).
} 
In the context of organizational work, experience-based knowledge and situational action are thus not conceived as deviations but must be analyzed within their own systems. The focus on situational action, as developed by ethnographic workplace studies (Knoblauch and Heath 1999), implies that the "how" of action is emphasized. In the sociological field, the concept of "experience-led subjectivizing action" (Böhle 2010:160, own translation) was developed in this context. This concept points to the fact that experience represents the basis of knowledge acquisition and considers the cognitive and practical interpretation of subjective elements such as feelings. Concerning informal forms of cooperation, the concept of "experienceled subjectivizing cooperation" was developed and opposes "planning-related objectivizing cooperation" (Böhle and Bolte 2002; Bolte and Porschen 2006). Experience-led subjectivizing cooperation is characterized by the following elements: the occasion, point in time and involved partners result from the situational problem; communication is based on common experiences; and the relation between the cooperative partners rests on mutual (work-related) familiarity (Böhle 2010:164). The fact that such forms of communication and cooperation cannot or can only partly be formalized results in the structurally informal character of social practices and processes. Regarding the example of cooperation, the difference between formal and informal forms of self-regulated cooperation lies specifically in the type of cooperative action and the resulting possibilities and limitations of formalization (Böhle 2010).

The differentiation between formality and informality is a classic distinction of organizational research. In the 1950s, Blau (1955) suggested that the functioning of an organization is based not only on formal structures but also on informal ones. Along with a few other scholars, Friedberg (1995) determined that deviation from the rules plays an important role for the functioning of an organization. According to Froschauer and Lueger (2015), formality and informality represent two forms of order that are closely interrelated but regulate different organizational areas. The authors argue that eventually, informality dominates formality. In the asylum bureaucracy, the informal poles of the dilemmas are also at least equally as important as the formal ones. The formal requirements - regulation, decision, focus on the individual and responsibility - represent the framework of action. Hence, formality creates a stable frame of social processes that are regulated through informality, "an expectation-robust framework that simultaneously serves as a ritual facade" (Froschauer and Lueger 2015:204, own translation). This abstract frame serves to externally legitimize decisions through binding procedures. To make the decision formally useful, it must be adjusted to this frame of formality. In addition, formalization offers an enforceable referral structure and simultaneously allows responsibility to be externalized. As explored above, this is a common practice of decision-making officials at the FAO.

By contrast, informal orders of interaction are based on relationships of trust and expectation-robust action. These informal orders enable flexibility and heterogeneity, as illustrated by caseworkers' individual approaches and strategies, and contribute to obscuring decision-making processes. It has also been noted that informal information networks represent one of the reasons why "decisions cannot be made 
transparent, even if officials were willing to do so" (Eule 2014:62). Unequal treatment and the lack of transparency are particularly criticized characteristics of the asylum procedure (Montgomery and Foldspang 2005; Linton 2014). Furthermore, informality requires experience and implicit, often inexplicable, knowledge (Froschauer and Lueger 2015). Officials' initial training, for example, is primarily based on the principle of learning by doing, which highlights the relevance of experience and implicit knowledge in the administration of asylum claims. The importance of socialization within the organizational culture becomes apparent in this context. As Martinez (2009:117) argues, "[A] formal organization also contains informal organizations composed of groups that form naturally, regardless of the formal, hierarchical structure. Informal organizations influence the perceptions and attitudes of group members and shape behavioral values and norms." In developing strategies, for example, regarding the treatment of asylum claimants in the interview, decision makers orient themselves not only toward administrative provisions but also toward their colleagues' practices. Froschauer and Lueger (2015:206, own translation) argue that often, "the explicit applicable rules are either not definitely known to the agents or the knowledge about them is unequally distributed." In the case of the FAO, decision makers who lack a legal education only know the legal basis of their actions to some extent. "In practice, it is the belief in specific formal rules and the legitimacy of this imagined order as well as the collective orientation toward this imagined order that connects the formal rules with everyday action" (ibid, own translation).

The sociological concept that addresses the functionality of the interplay of organizational formality and informality contributes to explaining the observed social practices with regard to the identified dilemmas. Formality is based on defined membership, clear rules and competences, enforceable rights and duties, impersonal and abstract relations, explicit knowledge, and a legal framework; here, domination allows for enforcement on an institutionalized basis. By contrast, informality is based on social inclusion, personal relations, common orientations, trust and solidarity, voluntary commitment, and implicit knowledge; here, power functions as the basis of enforcement. To some extent, formality establishes the confines for the room for maneuver by determining which rules have to be followed. However, it is only a frame that has to be animated; at that point, informality is the decisive factor (Froschauer and Lueger 2015).

This perspective shows how the two areas coexist and regulate different domains in asylum administration. Regulation, definitiveness, a focus on the individual human, and responsibility constitute the formal frame, whereas room for maneuver, uncertainty, a focus on the faceless case, and dissociation define practices on the informal level. Nevertheless, social practices cannot always be definitely located, and much takes place within an indeterminable gray zone, that is, in "tolerated zones of difference" with regard to rule application (Ortmann 2003), somewhere between formality and informality. Deviation from formality cannot always be clearly identified; instead, it is subject to interpretation, just as formal rules require interpretation, which is not always formally regulated down to the last detail (Froschauer and Lueger 2015). 


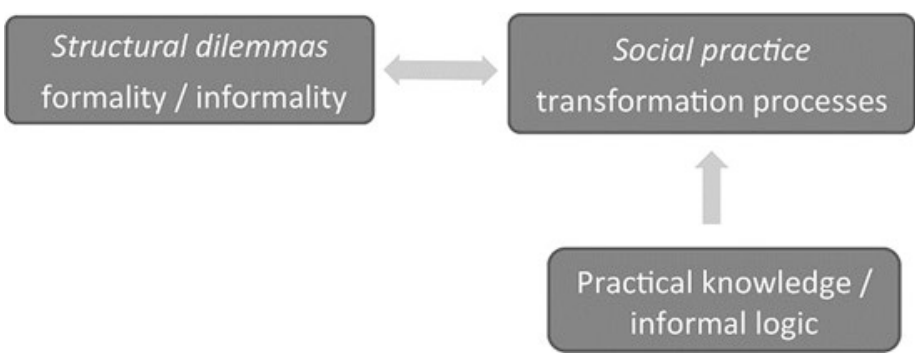

Fig. 9.1 Structuration in the context of formality and informality at the FAO. (Source: Own production)

Regarding the identified everyday dilemmas, officials' practices can be interpreted to the effect that the primarily informal practices - room for maneuver, uncertainty, orientation toward the faceless case, dissociation - experience a process of formalization to ensure that the case processing will include orientation toward the given norms, individual treatment of the claim, and a responsible, definite decision. By expressing the relation of practical knowledge, social action and structural dilemmas, Fig. 9.1 illustrates how social practices and structures in the asylum procedure mutually influence each other.

The way in which decision makers' social practices are based on practical knowledge and an informal logic has become clear. These practices reach their professional maturity through learning by doing; for example, they create informal categories of asylum claimants and their "cases," and they often maintain individual, informal relationships with experts or interpreters. At the same time, the legal and institutional structure in which the administration of asylum takes place requires formality - that is, not only a stable framework for social processes but also legitimation through binding procedures. To make a decision officially and formally useful, that decision has to fit the frame of formality. The different processes of transformation onto the formal level, such as the social construction of facts, must occur through social practices and are thus observable on the level of "doing" asylum decisions. Whereas structure represents a frame of reference for social action and thereby influences decision makers' opportunities, officials' room for maneuver enables them to stretch structure in one direction or another.

Both formality and informality as well as the explored transformation processes contribute to the reduction of complexity in the bureaucratic everyday. Decision makers' tasks include “tailoring" asylum claimants' experiences to legal and administrative requirements. Hence, complexity reduction must take place since we generally do not know enough, and system constraints, action chains and path dependencies make reasonable decisions unlikely (Ortmann 2003:138, own translation). Reducing complexity is also necessary since the endeavor to reach greater accuracy - such as the ongoing search for "true" facts in the asylum procedure could otherwise never end, resulting in agents' inability to act (Reichertz 1997). Ultimately, the asylum procedure is a bureaucratic process in which unambiguity must be produced and thus, alternatives must be excluded and made impossible. The abovementioned suppression and consolidation mechanisms are the consequence (Ortmann 1990). 


\section{References}

Barnes, J., \& Mackey, A. (2013). The Credo document. In C. A. F. M. Grütters, E. Guild, \& S. de Groot (Eds.), Assessment of credibility by judges in asylum cases in the EU. Oisterwijk: Wolf Legal Publishers.

Berger, P. L., \& Luckmann, T. (1975[1966]). The social construction of reality: A treatise in the sociology of knowledge. Reprinted, Harmondsworth: Penguin Books.

Bijker, W. E., \& Pinch, T. J. (2012). The social construction of facts and artefacts: Or how the sociology of science and the sociology of technology might benefit each other. In W. E. Bijker, T. P. Hughes, T. Pinch, \& D. G. Douglas (Eds.), The social construction of technological systems: New directions in the sociology and history of technology (pp. 11-44). Cambridge, MA: MIT Press.

Billig, M. (1988). Ideological dilemmas. A social psychology of everyday thinking. London: Sage Publ.

Blau, P. M. (1955). The dynamics of bureaucracy: A study of interpersonal relations in two government agencies. Chicago: University of Chicago Press.

Böhle, F. (2010). Arbeit als Handeln. In Handbuch Arbeitssoziologie, F. Böhle, G. Günter Voß, G. Wachtler, (2010th ed.). (pp. 151-176). Wiesbaden: VS Verlag für Sozialwissenschaften.

Böhle, F., \& Bolte, A. (2002). Die Entdeckung des Informellen: Der schwierige Umgang mit Kooperation im Arbeitsalltag. Frankfurt/Main: Campus Verlag.

Bolte, A., \& Porschen, S. (2006). Die Organisation des Informellen: Modelle zur Organisation von Kooperation im Arbeitsalltag. Wiesbaden: Springer.

Brodkin, E. Z. (2011). Policy work: Street-level organizations under new managerialism. Journal of Public Administration Research and Theory, 21(suppl_2), i253-i277. https://doi.org/10.1093/ jopart/muq093.

Dahlvik, J. (2017a). Entscheiden über Asyl: Organisationssoziologische Überlegungen zum Zusammenspiel von Formalität und Informalität im österreichischen AsylVerwaltungsverfahren. In C. Lahusen \& S. Schneider (Eds.), Asyl verwalten. Zur bürokratischen Bearbeitung eines gesellschaftlichen Problems (pp. 117-144). Bielefeld: transcript.

Dahlvik, J. (2017b). Asylum as construction work: Theorizing administrative practices. Migration Studies, 5(3), 369-388. https://doi.org/10.1093/migration/mnx043.

Discretion. (n.d.). In Cambridge English dictionary. Cambridge University Press 2017. Retrieved from http://dictionary.cambridge.org/dictionary/english/discretion

Dubois, V. (2010). The bureaucrat and the poor. Encounters in French welfare offices. Farnham: Ashgate.

Elias, N. (1976). Über den Prozeß der Zivilisation: Soziogenetische und psychogenetische Untersuchungen. Frankfurt am Main: Suhrkamp Verlag.

Eule, T. G. (2014). Inside immigration law: Migration management and policy application in Germany. Farnham: Ashgate Publishing Ltd.

Fassin, D. (2015). At the heart of the state: The moral world of institutions. London: Pluto Press.

Friedberg, E. (1995). Ordnung und Macht: Dynamiken organisierten Handelns. Frankfurt am Main: Campus-Verl.

Froschauer, U., \& Lueger, M. (2015). Informalität als organisationaler Basisrhythmus. In V. von Groddeck \& S. M. Wilz (Eds.), Formalität und Informalität in Organisationen (pp. 191-213). Wiesbaden: Springer Fachmedien Wiesbaden.

Giddens, A. (2011). The constitution of society: Outline of the theory of structuration. Cambridge: Polity Press.

Goodman, S., \& Speer, S. A. (2007). Category use in the construction of asylum seekers. Critical Discourse Studies, 4(2), 165-185. https://doi.org/10.1080/17405900701464832.

Hacking, I. (1999). The social construction of what? Cambridge, MA: Harvard University Press.

Hjörne, E., Juhila, K., \& Van Nijnatten, C. (2010). Negotiating dilemmas in the practices of streetlevel welfare work. International Journal of Social Welfare, 19(3), 303-309. 
Hupe, P., Hill, M., \& Buffat, A. (2015). Understanding street-level bureaucracy. Bristol: Policy Press.

Innes, A. J. (2010). When the threatened become the threat: The construction of asylum seekers in British media narratives. International Relations, 24(4), 456-477. https://doi. org/10.1177/0047117810385882.

Jubany, O. (2017). Screening asylum in a culture of disbelief: Truths, denials and skeptical borders. Berlin: Springer.

Jun, J. S. (2006). The social construction of public administration: Interpretive and critical perspectives. Albany: State University of New York Press.

Knoblauch, H., \& Heath, C. (1999). Technologie, Interaktion und Organisation: die Workplace Studies. Schweizerische Zeitschrift Für Soziologie, 25(2), 163-181. http://nbn-resolving.de/ urn:nbn:de:0168- ssoar-839.2.

Lacroix, M. (2004). Canadian refugee policy and the social construction of the refugee claimant subjectivity: Understanding refugeeness. Journal of Refugee Studies, 17(2), 147-166. https:// doi.org/10.1093/jrs/17.2.147.

Latour, B. (2003). The promises of constructivism. In D. Ihde \& E. Selinger (Eds.), Chasing technoscience: Matrix for materiality (pp. 27-46). Bloomington: Indiana University Press.

Latour, B., \& Woolgar, S. (1986). Laboratory life. The construction of scientific facts. Princeton: Princeton University Press.

Linton, R. (2014). A presumption of disclosure: Towards greater transparency in asylum proceedings. Seattle University Law Review, 38, 1069.

Lipsky, M. (2010). Streel-level bureaucracy: Dilemmas of the individual in public services (30th anniversary expanded). New York: Russell Sage Foundation.

Long, K. (2013). When refugees stopped being migrants: Movement, labour and humanitarian protection. Migration Studies, 1(1), 4-26. https://doi.org/10.1093/migration/mns001.

Lowe, A. (2004). Methodology choices and the construction of facts: Some implications from the sociology of scientific knowledge. Critical Perspectives on Accounting, 15(2), 207-231. https://doi.org/10.1016/S1045-2354(03)00067-4.

Lynn, N., \& Lea, S. (2003). 'A Phantom Menace and the New Apartheid': The social construction of asylum-seekers in the United Kingdom. Discourse \& Society, 14(4), 425-452. https://doi. org/10.1177/0957926503014004002.

Martinez, J. M. (2009). Public administration ethics for the 21 st century. Santa Barbara: Praeger.

Maynard-Moody, S. W., \& Musheno, M. C. (2003). Cops, teachers, counselors: Stories from the front lines of public service. Ann Arbor: University of Michigan Press.

Montgomery, E., \& Foldspang, A. (2005). Predictors of the authorities' decision to grant asylum in Denmark. Journal of Refugee Studies, 18(4), 454-467. https://doi.org/10.1093/refuge/fei040.

Mountz, A. (2010). Seeking asylum: Human smuggling and bureaucracy at the border. Minneapolis: University of Minnesota Press.

Noura, K. (2006). Travail de construction de la crédibilité, processus d'évaluation et de catégorisation des motifs de persécution: études de cas, les femmes réfugiées provenant d'ex-URSS. REVUE Asylon(s), Les Persécutions Spécifiques Aux Femmes., $N^{\circ} 1$.

Ortmann, G. (1990). Computer und Macht in Organisationen: mikropolitische Analysen. Opladen: Westdt. Verl.

Ortmann, G. (2003). Regel und Ausnahme. Paradoxien sozialer Ordnung. Frankfurt am Main: Suhrkamp.

Ortmann, G., Windeler, A., \& Sydow, J. (2000). Organisation als reflexive Strukturation. In G. Ortmann, J. Sydow, \& K. Türk (Eds.), Theorien der Organisation. Die Rückkehr der Gesellschaft. Wiesbaden: Westdeutscher Verlag.

Paquet, M. (2015). Bureaucrats as immigration policy-makers: The case of subnational immigration activism in Canada, 1990-2010. Journal of Ethnic and Migration Studies, 41(11), 18151835. https://doi.org/10.1080/1369183X.2015.1023185.

Pound, R. (1910). Law in books and law in action. American Law Review, 44, 12. 
Prottas, J. M. (1979). People-processing: The street-level bureaucrat in public service bureaucracies. Toronto: Lexington Books.

Reckwitz, A. (2002). Toward a theory of social practices. European Journal of Social Theory, 5(2), 243-263. https://doi.org/10.1177/13684310222225432.

Reckwitz, A. (2003). Grundelemente einer Theorie sozialer Praktiken. Eine sozialtheoretische Perspektive. Zeitschrift für Soziologie, 32(4), 282-301.

Reichertz, J. (1997). Plädoyer für das Ende einer Methodologiedebatte bis zur letzten Konsequenz. In T. Sutter (Ed.), Beobachtung verstehen, Verstehen beobachten (pp. 98-132). Opladen: VS Verlag für Sozialwissenschaften.

Squire, V. (2009). The exclusionary politics of asylum. Basingstoke: Palgrave Macmillan.

Stinchcombe, A. L. (2001). When formality works: Authority and abstraction in law and organizations. Chicago: University of Chicago Press.

Sweeney, J. A. (2009). Credibility, proof and refugee law. International Journal of Refugee Law, 21(4), 700-726. https://doi.org/10.1093/ijrl/eep02.

Zetter, R. (2007). More labels, fewer refugees: Remaking the refugee label in an era of globalization. Journal of Refugee Studies, 20(2), 172-192. https://doi.org/10.1093/jrs/fem011.

Open Access This chapter is licensed under the terms of the Creative Commons Attribution 4.0 International License (http://creativecommons.org/licenses/by/4.0/), which permits use, sharing, adaptation, distribution and reproduction in any medium or format, as long as you give appropriate credit to the original author(s) and the source, provide a link to the Creative Commons license and indicate if changes were made.

The images or other third party material in this chapter are included in the chapter's Creative Commons license, unless indicated otherwise in a credit line to the material. If material is not included in the chapter's Creative Commons license and your intended use is not permitted by statutory regulation or exceeds the permitted use, you will need to obtain permission directly from the copyright holder.

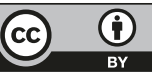

